\title{
Hematological and histological changes of black porgy Acanthopagrus schlegeli in ozonated recirculating systems
}

\author{
Pyong-Kih Kim ${ }^{1}$, Jae-Won Kim ${ }^{1}$ and Jeonghwan Park ${ }^{2 *}$
}

\begin{abstract}
This study evaluated hemato-histological changes of black porgy in recirculating aquaculture systems (RAS) with three different ozone doses (no ozone, $20 \mathrm{~g}$, and $40 \mathrm{~g}$ ozone/ $/ \mathrm{kg} \mathrm{feed} \mathrm{day}^{-1}$ ). During the 44-day study, black porgy did not show significant behavior changes or mortalities in both the ozonated systems displaying average total residual oxidants concentrations of 0.12 and $0.25 \mathrm{mg} / \mathrm{L}$. There were no differences in growth and blood parameters among the systems. However, histological alterations on gills and livers were observed in both the treatment systems. In the higher ozone dose, signs of cellular damage were more apparent. Although the ozone doses did not manifest a serious adverse effect on growth and hematological observations in this short-term study, an ozone dose should not exceed $20 \mathrm{~g}$ ozone/ $/ \mathrm{kg}_{\text {feed }}$ day $^{-1}$ for black porgy based on the histological result. In order to use ozone in a seawater RAS, further studies will be needed to evaluate long-term effects of total residual oxidants.
\end{abstract}

Keywords: Black porgy, Ozonated recirculating systems, Total residual oxidants, Hematology, Histophathology

\section{Background}

Marine finfish aquaculture in South Korea is mostly practiced in land-based flow-through or cage system that is operated in open environments. In this country, water temperatures suitable for marine aquaculture species are maintained for only 5-6 months (Park et al. 2008). During the winter months, productivity of marine aquaculture in Korea largely decreases due to frequent mortalities with low water temperatures. A high heating cost is often required to reduce the mortality and keep normal growth in such a flow-through system (Park et al. 2007). The contamination of coastal areas where most marine aquaculture operations are located has resulted in chronic disease outbreaks in open culture systems. These obstacles have reduced the efficiency of marine aquaculture in South Korea for the last decade. Thus, the demand for energy-efficient and biologically secure aquaculture systems is currently increasing for sustainable marine aquaculture production in South Korea.

\footnotetext{
*Correspondence: parkj@pknu.ac.kr

${ }^{2}$ Department of Marine Bio-Materials and Aquaculture, Pukyong National University, Busan 48513, South Korea

Full list of author information is available at the end of the article
}

Recirculating aquaculture systems (RAS) are known to be efficient in thermal control allowing for extended optimal culture period year-round in freshwater aquaculture, having shown potential for marine aquaculture. However, their use on a commercial scale has been limited, since the RAS requires a high start-up investment due to the necessity of water treatment equipment. Ozone has been recognized as an effective tool to control pathogens, solids, and other water quality parameters in aquaculture systems due to its strong oxidation power. Ozone has a high potential as a multi-purpose water treatment means besides disinfection, possibly reducing sizes of water treatment equipment for such solids removal and nitrification. Especially, ozone treatment has been used in intensive land-based systems such as recirculating aquaculture systems (Summerfelt 2003). In freshwater aquaculture systems, however, ozonation can result in serious gill damage and mortality at an ozone concentration of 0.008-0.06 mg/L (Bullock et al. 1997). Various lethal concentrations of residual ozone have been reported in a range of $0.01-0.1 \mathrm{mg} / \mathrm{L}$ for different freshwater and saltwater species in other studies (Goncalves and Gagnon 2011). In marine aquaculture systems, ozone reacts with naturally occurring bromine and produces 
residual oxidants that are relatively stable in water and highly toxic to aquatic animals (Hofmann 2000). Cooper (2002) indicated that ozone toxicity closely corresponded to total residual oxidants (TRO) rather than residual ozone itself in toxicity tests with various marine microalgae, invertebrates, and vertebrates. Ozone toxicity in seawater is mostly referred to as a function of total residual oxidants rather than as ozone itself (Crecelius 1979; Jones et al. 2006).

The black porgy is a historically important aquaculture resource in South Korea with a domestic production of 928 MT in 2014, exclusively produced from sea cages (Min et al. 2006; KOSIS 2015). Its feed conversion ratios range from 2.1 to 3.4 during warm water temperatures and 8 to 16 during cool water temperatures (KOSIS 2015) in sea cages. Chronic mortalities due to low water temperatures and coastal contamination have been problematic in reducing productivity. Thus, the main objectives of this study were to evaluate the effects of ozone on blood chemistry and histology of black porgy reared in the RAS.

\section{Methods}

\section{Experimental systems and fish}

Three independent recirculating aquaculture systems consisting of four square culture tanks $(1.0 \mathrm{~m} \mathrm{~L} \times$ $1.0 \mathrm{~m} \mathrm{~W} \times 1.0 \mathrm{~m} \mathrm{H})$, a sump $(0.5 \mathrm{~m} \mathrm{~L} \times 0.5 \mathrm{~m} \mathrm{~W} \times$ $1.0 \mathrm{~m} \mathrm{H})$, two radial solid settlers $(0.6 \mathrm{~m} \mathrm{D} \times 1.0 \mathrm{~m} \mathrm{H})$, a foam fractionator $(0.3 \mathrm{~m} \mathrm{D} \times 2.5 \mathrm{~m} \mathrm{H})$, trickling biofilter $(1.2 \mathrm{~m} \mathrm{D} \times 2.0 \mathrm{~m} \mathrm{H})$, and a $0.75 \mathrm{~kW}$ centrifugal pump were used in this study (Fig. 1). Filtered natural seawater was added to each system. Eighty fish (average weight of $334.5 \pm 29.2 \mathrm{~g}$ ) were stocked in each tank (total 320 fish in a system). Daily feeding rate was set at $1 \%$ of total body weight. Commercial extruded feed (50\% crude protein, $10 \%$ crude lipid, $10 \%$ crude ash, moisture $4.5 \%$, Woosung, Daejeon, South Korea) was offered three times a day at 9:00, 13:00, and 18:00. The same amount of feed was fed to the fish in each system for the entire study period. The water temperature was maintained at
$23{ }^{\circ} \mathrm{C}$ using electric heaters and the average salinity was 33.6 ppt. Solids were removed twice daily from each system by draining the solids settler. Water volume turnover rate of the system was about 36 times a day. Approximately, $10 \%$ of the system water was replaced daily to compensate for losses from solids removal and evaporation. The experiment was performed for 44 days during the winter months.

Ozone was generated (corona discharged method, Model LAB-I, Ozonetech Inc., Daejeon, South Korea) with pure oxygen gas and was injected through a Venturi pipe into the by-pass line between the centrifugal pump and foam fractionator. The by-pass was extended to $15 \mathrm{~m}$ length, and contact time was set at $4 \mathrm{~min}$. The treated water with ozone in the by-pass line returned to the sump before the centrifugal pump to prevent direct contact between the fish and the ozonated water. The control system (CS) was not ozonated, while the two treatment systems were ozonated at rates of $20 \mathrm{~g}$ (T20) and $40 \mathrm{~g}$ ozone $/ \mathrm{kg}$ feed day ${ }^{-1}$ (T40), respectively.

\section{Water quality and growth measurements}

Water temperature, dissolved oxygen, $\mathrm{pH}$, and salinity were measured once daily (model 556MPS Yellow Springs Instruments Inc., OH, USA). Total ammonia-N (TAN), nitrite- $\mathrm{N}\left(\mathrm{NO}_{2}-\mathrm{N}\right)$, nitrate- $\mathrm{N}\left(\mathrm{NO}_{3}-\mathrm{N}\right)$, total residual oxidants (TRO), and total suspended solids (TSS) were analyzed twice a week following initial setup, then once weekly thereafter. TAN, $\mathrm{NO}_{2}-\mathrm{N}, \mathrm{NO}_{3}-\mathrm{N}$, and TRO were analyzed according to the indophenol, azo-dye method, cadmium reduction, and the n,n-diethyl-p-phenylene diamine (DPD) methods, respectively (APHA 1995) using a spectrophotometer (DR/4000, Hach Co., Loveland, CO, USA). TRO concentrations were expressed as chlorine equivalents. Total suspended solid (TSS) concentrations were quantified by the filtering and weight method (APHA 1995).

After 44 days, feed conversion ratio (FCR), specific growth rate (SGR), and survival rate (SR) were calculated using the following equations.

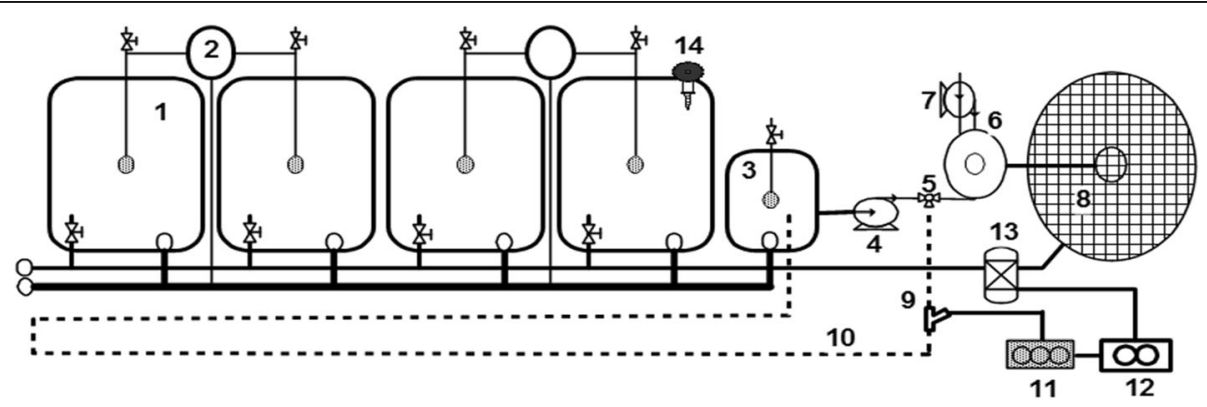

Fig. 1 Schematic diagram of experimental recirculating aquaculture system. 1 culture tank, 2 solid settler, 3 sump, 4 circulation pump, 5 three-way valve, 6 foam fractionators, 7 Venturi pump for foam fractionators, 8 trickling biofilter, 9 Venturi pipe for inhaling ozone, 10 tubular ozone contactor, 11 ozone generator, 12 oxygen generator, 13 oxygen contactor, 14 ORP probe 


$$
\begin{aligned}
& \mathrm{FCR}=\text { dry feed intake } / \text { wet weight gain } \\
& \mathrm{SR}(\%)=(\text { finial individuals } / \text { initial individuals }) \times 100 \\
& \mathrm{SGR}\left(\% \text { day }^{-1}\right)=\left[\left(\ln _{\mathrm{f}}-\ln \mathrm{W}_{\mathrm{i}}\right) / \text { days }\right] \times 100
\end{aligned}
$$

where $\mathrm{W}_{\mathrm{f}}$ is finial individual weight $(\mathrm{g})$, and $\mathrm{W}_{\mathrm{i}}$ is initial individual weight (g).

\section{Blood chemistry and histological examination}

Blood samples were randomly taken from 12 fish as a standard before stocking and 12 fish in each system (3 fish in each tank, a total of 12 fish from each system) at the end of the culture period to evaluate hematological and histological changes of the black porgy in the control and two different ozonation treatments. Hematocrit was measured with whole blood using micro-hematocrit tubes (9 uL volume) and a portable centrifuge (Ames Microspin, Bayer AG, Germany). The serum was separated by leaving the blood samples in the air for $30 \mathrm{~min}$ and centrifuging for $10 \mathrm{~min}$ at $3000 \mathrm{rpm}$. Cortisol was analyzed with Amerlex Cortisol RIA Kit (Kodak Clinical Diagnostic Ltd. Amersham, UK) and gamma counter (Wizard 1470, Wallac Co., USA). Glucose, protein, total cholesterol, triglycerol, aspartate transaminase (AST), and alanine transaminase (ALT) were measured with an automatic blood analyzer (Kodak Ektachem DT II System, USA). Hematological data measured for each parameter were pooled for statistical analyses.

Tissue samples of gills and livers were carefully removed from five fish in each group at the end of experiment. The tissues were immediately fixed in Bouin's solution as a histological fixative for $24 \mathrm{~h}$ and were embedded in paraffin wax after the process of dehydration with ethanol and cleaning with xylene. The tissues prepared were then sectioned at a thickness of 4-6 um using a rotary microtome (RM 2125, Leica Microsystems $\mathrm{GmbH}$, Frankfurt, Germany). The specimens were then stained with Mayer's hematoxylin for $4 \mathrm{~min}$ (nuclei staining) followed by $0.5 \%$ eosin for $1 \mathrm{~min}$ (chromatin staining). Also, in order to examine the species and distribution of mucus cells in the tissues, the Alcian blue/ periodic acid- Schiff (AB-PAS) method was used. The prepared specimens were first stained with Alcian-blue for $5 \mathrm{~min}$ and then oxidized with $0.5 \%$ periodic acid for $5 \mathrm{~min}$ followed by treatment of the Schiff reagent and Mayer's hematoxylin. The stained specimens were photographically examined using a light microscope (BX50F-3, Olympus Optical CO. LTD., Tokyo, Japan).

\section{Statistical analysis}

One-way analysis of variance (ANOVA) was used to determine the effects of ozonation on growth and hematological parameters; normality was satisfied by the Shapiro-Wilk test. Data given as a ratio such as survival were arc-sin transformed (Rowland et al. 2006). Analysis of covariance (ANCOVA) was performed to identify differences among treatments for water quality parameters. Duncan's post hoc test was utilized to compare means with equal variances, and the Games-Howell post hoc test was used to compare means with unequal variances (Golomazou et al. 2006; Ramirez et al. 2015). Data that did not satisfy the normality assumption were analyzed with Kruskal-Wallis non-parametric test followed by pairwise multiple comparison procedure. Differences were considered significant at $P<0.05$. Data were analyzed using SPSS 12 (SPSS Inc., Chicago, IL, USA).

\section{Results}

\section{Fish growth and water quality}

During the 44-day experiment, overall growth rates of black porgy were relatively low in both the control and treatment systems. There were no differences in growth parameters and survival among groups, indicating no adverse effects of ozonation on the growth performance during the period. Water quality parameters such as TAN, $\mathrm{NO}_{2}^{-}-\mathrm{N}, \mathrm{NO}_{3}-\mathrm{N}$, and TSS were maintained in acceptable ranges in control and treatment systems over the period $(P<0.05)$. TAN concentration was lowest in $\mathrm{T} 20$, while CS and T40 did not differ. $\mathrm{NO}_{2}^{-}-\mathrm{N}$ and TSS concentrations were highest at the control system $(P<0.05$, Table 1). There was no difference between control and treatment systems for $\mathrm{NO}_{3}^{-}-\mathrm{N}$ concentrations $(P<0.05)$. TSS concentrations in T20 and T40 were significantly lower than that in CS. TRO concentration in T40 with the higher ozone dose was higher than T20 $(P<0.05$, Table 2$)$.

\section{Hematological and histological changes}

Hematocrit and AST levels were not significantly different among the control and treatment systems and from the initial level $(P>0.05)$. Glucose and ATL levels significantly increased compared to the initial level $(P>0.05)$, but there were no differences between the control and treatment systems $(P<0.05)$. Black porgy in both control and treatment systems displayed a significant increase in cortisol compared to its initial level $(P<0.05)$, but there were no differences between control and treatments $(P>0.05$, Table 3$)$.

Figure 2a shows normal tissues within the gill filaments and lamellae of control fish at the end of experiment. In the lower ozone treatment system (T20), the onset of edema was observed in a wide range of epithelia gill cells, resulting in hypertrophy and clubbing of gill lamellae (Fig. 2b). In the higher ozone dose (T40), more extensive lesions were seen including hypertrophy and hyperplasia in some organs and fusion of gill lamellae (Fig. 2c). In some individuals, fusion of gill lamellae was aggravated, engendering epithermal cell lifting and necrosis of gill lamellae (Fig 2d). 
Table 1 Water quality changes in the control (CS no ozone) and ozonated systems (T20: $20 \mathrm{~g}$ ozone/kg feed day ${ }^{-1}, \mathrm{~T}_{40}: 40 \mathrm{~g}$ ozone/kg feed day ${ }^{-1}$ )

\begin{tabular}{lllll}
\hline & CS & T20 & T40 & $P$ value \\
\hline Ammonia nitrogen $(\mathrm{mg} / \mathrm{L})$ & $0.57 \pm 0.11^{\mathrm{b}}$ & $0.46 \pm 0.08^{\mathrm{a}}$ & $0.54 \pm 0.12^{\mathrm{b}}$ & 0.005 \\
Nitrite nitrogen $(\mathrm{mg} / \mathrm{L})$ & $0.42 \pm 0.06^{\mathrm{b}}$ & $0.30 \pm 0.07^{\mathrm{a}}$ & $0.35 \pm 0.08^{\mathrm{a}}$ & 0.001 \\
Nitrate nitrogen $(\mathrm{mg} / \mathrm{L})$ & $39.2 \pm 6.1$ & $44.0 \pm 3.1$ & $38.7 \pm 4.3$ & 0.089 \\
Total suspended solid $(\mathrm{mg} / \mathrm{L})$ & $2.12 \pm 0.19^{\mathrm{b}}$ & $1.31 \pm 0.25^{\mathrm{a}}$ & $1.34 \pm 0.05^{\mathrm{a}}$ & 0.036 \\
Total residual oxidant $(\mathrm{mg} / \mathrm{L})$ & $\mathrm{NA}^{\mathrm{a}}$ & $0.12 \pm 0.09^{\mathrm{a}}$ & $0.25 \pm 0.12^{\mathrm{b}}$ & 0.000 \\
\hline
\end{tabular}

${ }^{\mathrm{a}} \mathrm{NA}$ not assessed

${ }^{b}$ Values are means $\pm \mathrm{SD}(\mathrm{mg} / \mathrm{L})$ of triplicate groups. Values with the same superscript within the same row are not significantly different at $P<0.05$ based on Duncan's multiple range test

Histological alterations were not observed on livers of black porgy in the control system (Fig. 3a), while the fish in the lower ozone dose (T20) displayed a positive reaction to Alcian blue staining in bile ductules, indicating swelling hepatic cells and degeneration of zymogen granules (Fig. 3b, c). Degeneration of gallbladders and abnormal pancreases were often observed in the fish at the higher ozone treatment (T40, Fig. 3d).

\section{Discussion}

Fish in both the control and treatment systems had limited growth during the 44 day experiment. Factors contributing to the slow growth could include the fact that fish were close to market size. Also, nutritional requirements and optimal stocking densities for black porgy have not been well established yet. Black porgy in ozonated systems displayed no behavior changes and reduction in growth and survival compared to fish in the control system, although hematological and histological alterations were observed in both the treatment systems.

In the higher ozone dose $\left(40 \mathrm{~g}\right.$ ozone $/ \mathrm{kg}$ feed day $\left.{ }^{-1}\right)$, signs of cellular damage in black porgy were apparent in gills and livers. According to Cooper (2002), microalgae, crabs, and lobster exhibited a high percentage of mortality $(50-100 \%)$ at $0.14-1.0 \mathrm{mg} / \mathrm{L}$ of TRO. In flowthrough tests, striped bass displayed a $96-\mathrm{h} \mathrm{LC}_{50}$ of 0.06-0.2 $\mathrm{mg} / \mathrm{L}$ for different life stages, while perch had a higher tolerance to TRO than striped bass; a $96-\mathrm{h} \mathrm{LC}_{50}$ of $0.2-0.38 \mathrm{mg} / \mathrm{L}$. Richardson et al. (1983) reported a 96-h $\mathrm{LC}_{30}$ of $0.2 \mathrm{mg} / \mathrm{L}$ for adult white perch (Morone americana). Schroeder et al. (2010) found that Pacific white shrimp (Litopenaeus vannamei) were likely less sensitive to TRO compared to fish species; a $96-\mathrm{h} \mathrm{LC}_{50}$ of $0.5 \mathrm{mg} / \mathrm{L}$ and a no-observed effect concentration of $0.06 \mathrm{mg} / \mathrm{L}$. Chinese white shrimp (Penaeus chinensis) survived for $48 \mathrm{~h}$ when exposed to a TRO concentration of $1 \mathrm{mg} / \mathrm{L}$, while olive flounder (Paralichthys olivaceus) lived only $3 \mathrm{~h}$ at that concentration (Jiang et al. 2001). Collectively, TRO seem to exhibit very severe toxicity in a range of $0.1-1.0 \mathrm{mg} / \mathrm{L}$ to most saltwater species, resulting in mass mortality within $48-96 \mathrm{~h}$.

In the present study, unlike results of previous studies, black porgy did not show significant mortality and growth reduction for 44 days at TRO concentrations of $0.12 \mathrm{mg} / \mathrm{L}$ (T20) and $0.25 \mathrm{mg} / \mathrm{L}$ (T40), which are within reported acute toxic levels for other saltwater or marine species. Similar to our study, juvenile turbot exposed to different TRO concentrations $(0.06,0.10$, and $0.15 \mathrm{mg} /$ L) in recirculating systems showed high survival rates and no growth reduction for 21 days when compared to fish in unozonated systems; however, they reported minor gill damage and impaired blood chemistry at 0.10 and $0.15 \mathrm{mg} / \mathrm{L}$ (Reiser et al. 2010). These values are slightly lower than the values observed in our study but virtually acute concentrations that can manifest mass mortality in very short time to most of saltwater species.

When white perch and rainbow trout were exposed to oxidants such as chlorine, ozone, and residual oxidants, short-term increased levels of hematocrit, hemoglobin, and red blood cells are often reported (Bass and Heath 1977; Block et al. 1978; Richardson et al. 1983). When the concentration of total residual oxidants increased and approached lethal levels (0.039 $\mathrm{mg} \mathrm{TRO} / \mathrm{L})$, olive flounder Paralichthys olivaceus also showed increased

Table 2 Growth performance of black porgy Acanthopagrus schlegeli in the control (CS: no ozone) and ozonated systems (T20: g ozone/kg feed day ${ }^{-1}$, T40: $40 \mathrm{~g}$ ozone/kg feed day ${ }^{-1}$ ) after 44 days culture

\begin{tabular}{lllll}
\hline & CS & T20 & T40 & $P$ value \\
\hline Initial biomass (g) & $26,620 \pm 482$ & $26,200 \pm 210$ & $26,334 \pm 370$ & 0.909 \\
Final biomass (g) & $29,020 \pm 484$ & $29,080 \pm 486$ & $29,010 \pm 308$ & 0.800 \\
Feed conversion ratio & $3.09 \pm 0.20$ & $2.97 \pm 0.34$ & $3.19 \pm 0.27$ & 0.637 \\
Specific growth rate (\%/day) & $0.22 \pm 0.00$ & $0.23 \pm 0.03$ & $0.22 \pm 0.03$ & 0.650 \\
Survival (\%) & $98.3 \pm 2.9$ & $99.2 \pm 1.4$ & $99.2 \pm 1.4$ & 0.850 \\
\hline
\end{tabular}


Table 3 Changes in hematological parameters of black porgy Acanthopagrus schlegeli in the control (CS: no ozone) and ozonated systems (T20: $20 \mathrm{~g}$ ozone/kg feed day ${ }^{-1}$, and T40: $\mathrm{g}$ ozone/kg feed day ${ }^{-1}$ ) after 44 days culture

\begin{tabular}{llllll}
\hline & Initial & CS & T20 & T40 & $P$ value \\
\hline Hematocrit (\%) & $35.7 \pm 7.5$ & $39.4 \pm 3.3$ & $38.2 \pm 4.9$ & $39.6 \pm 5.5$ & 0.384 \\
Glucose $(\mathrm{mg} / \mathrm{dL})$ & $51.3 \pm 8.6^{\mathrm{a}}$ & $63.7 \pm 10.1^{\mathrm{b}}$ & $64.3 \pm 9.6^{\mathrm{b}}$ & $63.2 \pm 8.5^{\mathrm{b}}$ & 0.009 \\
AST $(\mathrm{IU} / \mathrm{L})$ & $14.8 \pm 6.3$ & $20.5 \pm 7.1$ & $18.8 \pm 8.3$ & $24.5 \pm 11.8$ & 0.084 \\
ALT $(\mathrm{IU} / \mathrm{L})$ & $1.31 \pm 0.63^{\mathrm{a}}$ & $2.67 \pm 0.82^{\mathrm{b}}$ & $2.50 \pm 0.55^{\mathrm{b}}$ & $3.00 \pm 0.63^{\mathrm{b}}$ & 0.000 \\
Cortisol $(\mu \mathrm{g} / \mathrm{dL})$ & $0.68 \pm 0.51^{\mathrm{a}}$ & $2.22 \pm 0.79^{\mathrm{b}}$ & $2.69 \pm 0.97^{\mathrm{b}}$ & $2.36 \pm 1.61^{\mathrm{b}}$ & 0.000 \\
\hline
\end{tabular}

aalues are means \pm SD of triplicate groups

${ }^{b}$ Values with the same superscript within the same row are not significantly different at $P<0.05$ based on Duncan's multiple range test

hematocrit, hemoglobin, red blood cells, glucose, and osmolality (Kim et al. 1999). However, Reiser et al. (2010) reported that levels of hematocrit, hemoglobin, and cortisol of juvenile turbot reared in recirculating systems were leveled off and returned to normal after spiking for the first several days at a TRO range of 0.06$0.15 \mathrm{mg} / \mathrm{L}$. Good et al. (2011) also reported no significant effect of ozone on hematocrit, hemoglobin, and most blood chemistry parameters of rainbow trout reared in ozonated recirculating systems at an oxidation/reduction potential (ORP) set-point of $250 \mathrm{mV}$ for 350 culture days. In these studies, alterations were observed in gills and livers in ozonated systems. However, authors concluded that the alterations were mostly subclinical and did not appear to affect fish health under the given culture conditions. In the present study, the results of the blood parameters and histological examination of gills and livers agreed with previous studies (Reiser et al. 2010; Good et al. 2011).

Ozone toxicity can vary depending on species and life stage (Summerfelt 2003). Usually, aquatic organisms at early life stages tend to be more susceptible to TRO toxicity. The fish used in our study were approaching marketable size (average weight of $334.5 \mathrm{~g}$ ) and could show a higher tolerance to toxic materials. The black porgy has a wide range of salinity tolerance and can grow in freshwater in an extended period with high survival and growth rates (Min et al. 2003; Min et al. 2006). This adaptive ability of the fish could contribute to the higher tolerance to the TRO concentration over a prolonged period.

Most previous studies of ozone toxicity were conducted in batch or flow-through tanks with zero or low

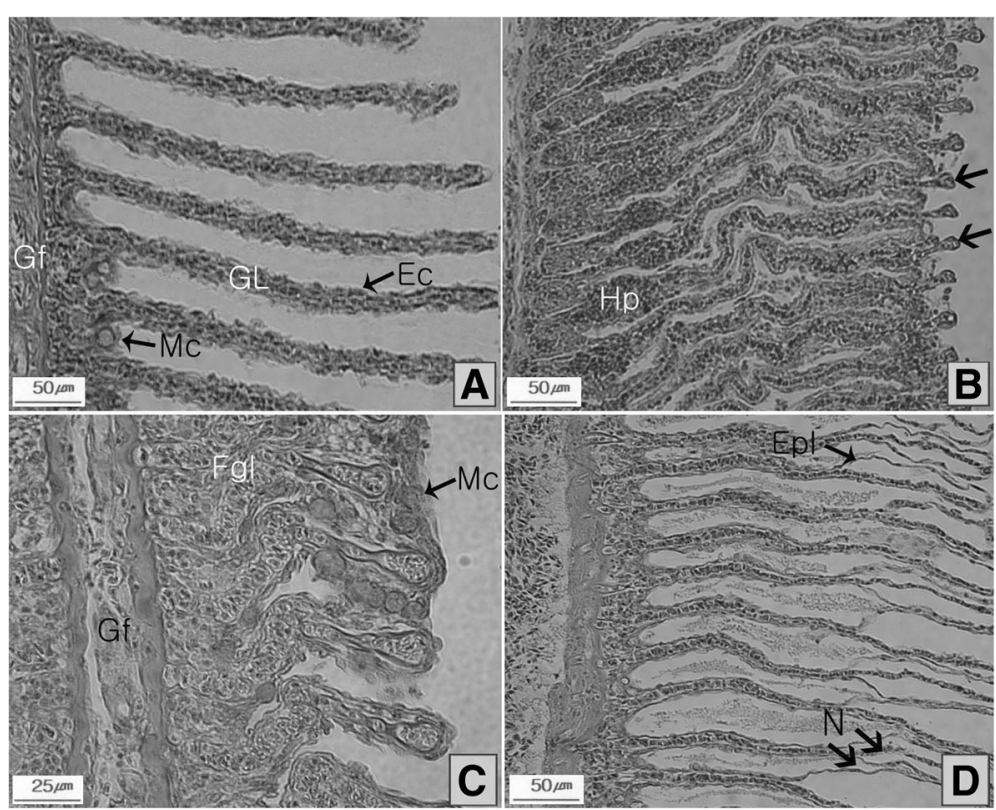

Fig. 2 Histological changes of the gill of black porgy Acanthopagrus schlegeli in the control (CS no ozone) and ozonated systems (T20: $20 \mathrm{~g}$ ozone/kg feed day ${ }^{-1}$ and T40: $40 \mathrm{~g}$ ozone/ $/ \mathrm{kg}$ feed day $^{-1}$ ) after 44 days of culture. a Control (CS). Note the gill filament (Gf), gill lamellae (GI). b T20 group. Hematoxylin and eosin (H\&E) section showing the extensive edema of epithelial cells and hypertrophy and clubbed type of gill lamellae. c T20 and T40 groups. Note the hypertrophy, hyperplasia, and fusion of gill lamellae. d T40 group. H\&E section showing the epithelial cell lifting (arrow) and the necrosis of gill lamellae 


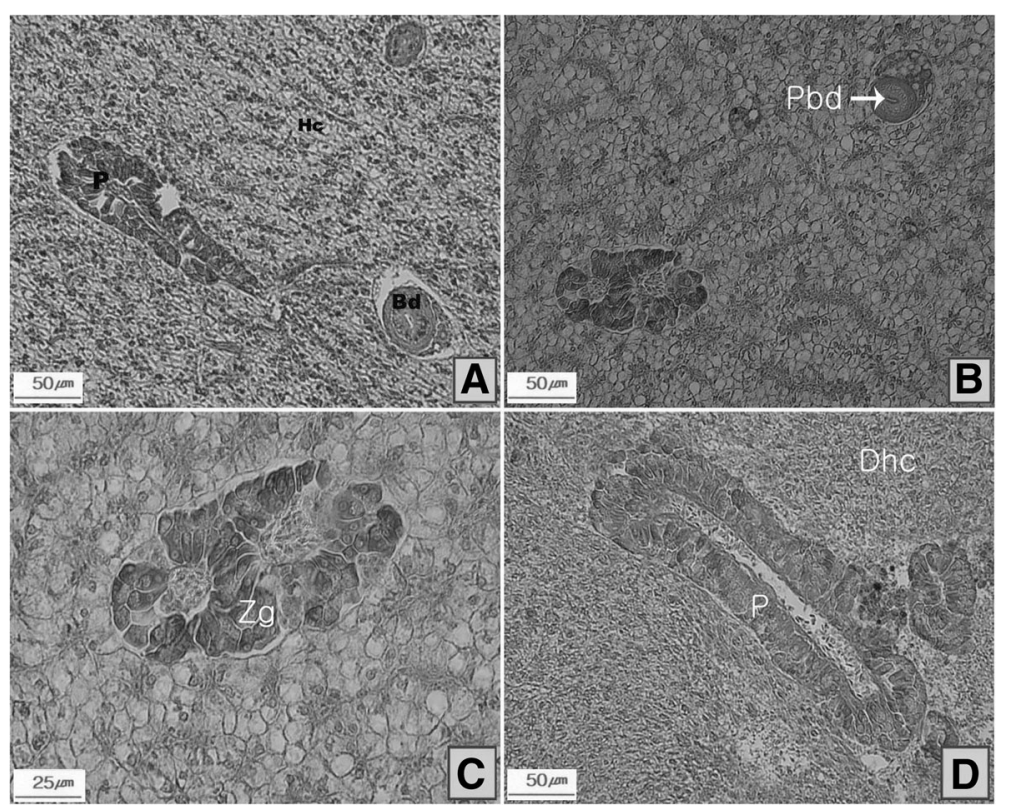

Fig. 3 Histological changes in the liver of black porgy Acanthopagrus schlegeli in the control (CS no ozone) and ozonated systems (T20: $20 \mathrm{~g}$ ozone/kg feed day ${ }^{-1}$ and T40: $40 \mathrm{~g}$ ozone/ $\mathrm{kg}_{\text {feed }} \mathrm{day}^{-1}$ ) after 44 days of culture. a Control (CS). Note the hepatic cell (Hc), pancreas (P), and bile duct (Bd). b T20 group. AB-PAS section showing the free surface of alcian blue positive reaction in the bile duct and the swelling hepatic cells and degeneration of zymogen granules. c T20 group. The magnitude of hepatic cells and pancreas of figure $\mathbf{b}$. $\mathbf{d}$ T40 group. Note the degeneration of hepatic cells and the abnormal pancreas

loads of organic and nitrogen compounds in the water. The results from these studies tend to indicate relatively high toxicity to aquatic animals at lower TRO concentrations. Studies conducted in intensive culture systems with high organic loads suggest relatively high tolerance of aquatic animals to TRO and/or ozone levels (Reiser et al. 2010; Good et al. 2011), corresponding to the results of the present study. The effect of ozonation on water chemistry in saltwater is complex, and other water quality parameters could affect the formation of bromide (Hofmann 2000). Once ozonation is applied in saltwater, bromide will first be oxidized to free bromine $(\mathrm{HOBr} /$ $\mathrm{OBr}^{-}$), but also can exist in other forms such as $\mathrm{BrO}_{2}^{-}$ and $\mathrm{BrO}_{3}^{-}$(Song 1996). When ammonia nitrogen is present, free bromine will react with ammonia nitrogen, forming ammoniacal bromines and some other resultant compounds such as $\mathrm{NH}_{2} \mathrm{Br}_{2}, \mathrm{NHBr}_{2}, \mathrm{NBr}_{3}, \mathrm{Br}_{2}$, and $\mathrm{Br}_{3}^{-}$ (Galal-Gorchev and Morris 1965; Johnson and Overby 1971). Among these various forms of oxidants resulting from ozonation, such as $\mathrm{HOBr}$ and $\mathrm{OBr}^{-}$, are the most toxic to aquatic organisms. Common colorimetric and spectrometric methods measure a total yield of bromide (Hofmann 2000). The mole fraction of these oxidants changes with $\mathrm{pH}$, nitrogen:bromine ratio, and other water quality parameters (Johnson and Overby 1971; Song 1996). Thus, ozonation in saltwater could manifest different toxicities at the same TRO concentration depending on other water quality conditions.
Furthermore, the analysis methods could be insensitive and/or inaccurate due to impurities such as humic/fuvic substances in water (Pinkernell et al. 2000). In the study by Neal et al. (2007), bromide concentrations measured with colorimetry were higher than those with ion chromatography (IC) for rainfall, cloud water, and river water, since the colorimetry could responds to bromate, which is less toxic than the other residual oxidants. In our study, the experimental systems were not equipped with intensive solids removal devices such as drum, bead, and/or sand filters. Ozonation was applied to primarily control suspended and fine solids, minimizing intensive equipment for solids removal, which results in heavy investments. Average concentrations of dissolved organic carbon were $11.2 \mathrm{mg} / \mathrm{L}$ (T20) and $12.1 \mathrm{mg} / \mathrm{L}$ (T40) (Park et al. 2011). Water colors were improved in ozonated systems over the experimental period, but culture water was still stained a yellow color, showing average true color of 10.1 unit Pt-Co (T20) and 8.6 unit Pt-Co (T40) (Park et al. 2013). Dissolved organic carbon such as humic and fulvic substances that result in water color likely interfered in colorimetry (Neal et al. 2007). It is known that color can interfere in chemical analysis of water quality (APHA 1995). In other studies, highly overestimated values of bromate were reported with spectrophotometric methods due to the presence of humic substances (Mitrakas et al. 2000; Mitrakas 2007). The interference of color due to humic substances has 
often been reported in colorimetric analyses for chloride, fluoride, nitrite, nitrate, phosphate, and sulfate (Menke 1962). Further studies are needed to investigate the effect of humic/fulvic substances on the measurement of residual oxidants to quantify the toxicity of residual oxidants in aquaculture systems with heavy color substances and/or dissolved organic loads.

\section{Conclusions}

In summary, although the ozone doses did not manifest a serious adverse effect on growth and hematological observations in this short-term study, an ozone dose should not exceed $20 \mathrm{~g}$ ozone $/ \mathrm{kg}$ feed day $^{-1}$ in black porgy based on the histological result. In order to use ozone as a means of solids control in seawater RASs, further studies will be needed to evaluate a long-term effect of TRO.

\section{Abbreviations}

AB-PAS: The alcian blue/periodic acid- Schiff; ALT: Alanine transaminase; ANCOVA: Analysis of covariance; ANOVA: Analysis of variance; AST: Aspartate transaminase; CS: Control system; DPD: n,n-diethyl-p-phenylene diamine; FCR: Feed conversion ratio; SGR: Specific growth rate; SR: Survival rate; T20: Treatment at an ozonation rate of $20 \mathrm{~g}$ ozone $/ \mathrm{kg}$ feed day ${ }^{-1}$; T40: Treatment at an ozonation rate $40 \mathrm{~g}$ ozone $/ \mathrm{kg}_{\text {feed }}$ day ${ }^{-1}$; TAN: Total ammonia-N; TRO: Total residual oxidants; TSS: Total suspended solids

\section{Acknowledgements}

This work was supported by a Research Grant of Pukyong National University (2016 year). The authors wish to thank Seongdeok Park, Wooguen Park, and Jeonglim Choi for their efforts in data collection and water quality analysis, and Jongku Kim, representative of ASTEC for research collaboration. Luke Roy and Andrew Mitchell provided helpful comments on an early version of the manuscript.

\section{Funding}

This study is financially supported by Pukyong National University.

\section{Availability of data and materials}

All datasets generated and/or analyzed during the current study are available from the corresponding author on reasonable request.

\section{Authors' contributions}

P-KK has provided overall concepts of experiment and specialties of aquaculture management. JP has responsibilities on performing the study and analyzing

experimental information. J-WK collected tissue samples and performing histological examinations. All authors read and approved the final manuscript.

\section{Ethics approval}

Experimental protocols followed the guidelines of the Animal Care and Use Committee of Pukyong National University.

\section{Consent for publication}

Not applicable.

\section{Competing interests}

The authors declare that they have no competing interests.

\section{Publisher's Note}

Springer Nature remains neutral with regard to jurisdictional claims in published maps and institutional affiliations.

\section{Author details}

'Department of Aquaculture, Gangwon State University, Gangneung 25425, South Korea. ${ }^{2}$ Department of Marine Bio-Materials and Aquaculture, Pukyong National University, Busan 48513, South Korea.

Received: 17 August 2017 Accepted: 14 December 2017

Published online: 22 January 2018

\section{References}

APHA. Standard methods for the examination of water and wastewater. 19th ed. Washington D.C: American Public Health Association; 1995.

Bass ML, Heath AG. Toxicity of intermittent chlorination to bluegill, Lepomis macrochirus: interaction with temperature. Bull Environ Contam Toxicol. 1977; 17:416-23.

Block RM, Burton DT, Gullans SR, Richardson LB. Respiratory and osmoregulatory responses of with perch (Morone Americana) exposed to chlorine and ozone in estuarine waters. In: Jolly RL, Gorchev H, Hamilton Jr DH, editors. Water chlorination environmental impact and health effects. Ann Arbor: Ann Arbor Science; 1978. p. 351-60.

Bullock GL, Summerfelt ST, Noble A, Weber A, Durant MD, Hankins JA. Ozonation of a recirculating rainbow trout culture system I. Effects of bacterial gill disease and heterotrophic bacteria. Aquaculture. 1997;158:43-55.

Cooper WJ. Ozone, seawater and aquatic nonindigenous species: Testing a fullscale ozone ballast water treatment system on an American oil tanker. Abstract 11th International Conference on Aquatic Invasive Species. Alexandria, VA. USA. 2002

Crecelius EA. Measurements of oxidants in ozonated seawater and some biological reactions. J Fish Res Board Can. 1979;36:1006-8.

Galal-Gorchev H, Morris JC. Formation and stability of bromamide, bromimide and nitrogen tribromide in aqueous solution. Inorg Chem. 1965:4:899-905.

Golomazou E, Athanassopoulou F, Karagouni E, Vagianou S, Tsantilas H, Karamanis D. Efficacy and toxicity of orally administrated anti-coccidial drug treatment on Enteromyxum leei infections in sharpnout seabream (Diplodus puntazzo C.). Isr J Aquacult Bamidgeh. 2006;58:157-69.

Goncalves AA, Gagnon GA. Ozone application in recirculating aquaculture: an overview. Ozone Sci Eng. 2011;33:345-67.

Good C, Davidson J, Welsh C, Snekvik K, Summerfelt ST. The effects of ozonation on performance, health and welfare of rainbow trout Oncorhynchus mykiss in low-exchange water recirculation aquaculture systems. Aquac Eng. 2011:44: 97-102.

Hofmann R. Using ammonia to inhibit bromate formation during ozonation. Ph. D. dissertation. Toronto: University of Toronto; 2000.

Jiang G, Liu Y, Yang D, Lu Y. Toxicity of ozonated sea water to Penaeus chinensis and Paralichthys olivaceus. Mar Sci. 2001;25:11-3.

Johnson JD, Overby R. Bromine and bromamine disinfection chemistry. ASCE J Sanit Eng Div. 1971;97:617-28.

Jones AC, Gensemer RW, Stubblefield WA, Van Genderen E, Dethloff GM, Cooper WJ. Toxicity of ozonated seawater to marine organisms. Environ Toxicol Chem. 2006;25:2683-91.

Kim HY, Oh MJ, Jung SJ. Acute toxicity of ozone on survival and physiological conditions of olive flounder, Paralichthys olivaceus. J. Fish Pathol. 1999:32-40. (Korean)

KOSIS (Korean Statistical Information Service). Korea National Statistical Office. Daejeon: KOSIS Statistical DB: 2015.

Menke CG. Removal of natural color-causing substances in laboratory analysis. Am Water Works Assoc. 1962:54:303.

Min BH, Bang IC, Choi WS, Chang YJ. Evaluation of fish flesh and profitability of black porgy (Acanthopagrus schlegeli) cultured in freshwater. J Kor Aquac Soc 2006;19:14-8. (Korean).

Min BH, Kim BK, Hur JW, Bang IC, Byun SK, Choi CY, Chang YJ. Physiological responses during freshwater acclimation of seawater-cultured black porgy (Acanthopagrus schlegeli). Kor J Ichthyol. 2003;15:224-34. (Korean).

Mitrakas M. Bromate determination in water using chlorpromazine after correction of chlorinating agents and humic substances interference. J Anal Chem. 2007; 62:1055-63.

Mitrakas M, Tzimou-Tsitouridou R, Keramidas V. Interference of humic substances in the spectrophotometric determination of bromate by phenothiazines in natural waters. Int J Environ Anal Chem. 2000;78:343-51.

Neal M, Neal C, Wickham H, Harman S. Determination of bromide, choride, fluoride, nitrate and sulphate by ion chromatography: comparison of methodologies for 
rainfall, cloud water and river waters at the Plynlimon catchments of mid-Wales. Hydrol Earth Syst Sci. 2007;11:294-300,

Park J, Kim HB, Kim PK, Jo JY. The growth of disk abalone, Haliotis discus hannai at different culture densities in a pilot-scale recirculating aquaculture system with a baffled culture tank. Aquac Eng. 2008;38:161-70.

Park J, Kim PK, Jo JY. Growth performance of disk abalone Haliotis Discus hannai in pilot- and commercial-scale recirculating aquaculture systems. Aquac Int. 2007;16:191-202.

Park J, Kim PK, Lim T, Daniels HV. Ozonation in seawater recirculating systems for black seabream Acanthopagrus schlegelii (Bleeker): effects on solids, bacteria, water clarity, and color. Aquac Eng. 2013;55:1-8.

Park J, Kim Y, Kim PK, Daniels HV. Effects of two different ozone doses on seawater recirculating systems for black sea bream Acanthopagrus schlegeli (Bleeker): removal of solids and bacteria by foam fractionation. Aquac Eng. 2011:44:19-24.

Pinkernell U, Nowack B, Gallard H, von Gunten V. Methods for the photometric determination of reactive bromine and chlorine species with ABTS. Water Res. 2000;34:4343-50.

Ramirez B, Ortega L, Monero D, Tuya F, Haroun R. Monitoring a massive scape of European sea bass (Dicentrarchus labrax) at an oceanic island: potential species establishment. J Aquac Res Dev. 2015;6:1-9.

Reiser S, Schroeder JP, Wuertz S, Kloas W, Hanel R. Histological and physiological alterations in juvenile turbot (Psetta maxima, L.) exposed to sublethal concentrations of ozone-produced oxidants in ozonated seawater. Aquaculture. 2010;307:157-64.

Richardson LB, Burton DT, Burton D, Block RM. Lethal and sublethal exposure and recovery effects of ozone-produced oxidants on adult white perch (Morone Americana Gmlin). Water Res. 1983;17:205-13.

Rowland SJ, Mifsud C, Nikon M, Boyd P. Effects of stocking density on the performance of the Australian freshwater silver perch (Bidyanus bidyanus) in cages. Aquaculture. 2006;253:301-8.

Schroeder JP, Gärtner A, Waller U, Hanel R. The toxicity of ozone-produced oxidants to the Pacific white shrimp Litopenaeus vannamei. Aquaculture. 2010;305:6-11.

Song R. Ozone-bromide-NOM interactions in water treatment. Ph.D. Dissertation. Urbana-Champaign: University of Illinois at Urbana-Champaign; 1996.

Summerfelt S. Ozonation and UV irradiation-an introduction and examples of current applications. Aquac Eng. 2003;28:21-36.

\section{Submit your next manuscript to BioMed Central and we will help you at every step:}

- We accept pre-submission inquiries

- Our selector tool helps you to find the most relevant journal

- We provide round the clock customer support

- Convenient online submission

- Thorough peer review

- Inclusion in PubMed and all major indexing services

- Maximum visibility for your research

Submit your manuscript at www.biomedcentral.com/submit

) Biomed Central 